\title{
Isozyme Variations in some Wheat Genotypes at Siwa Oasis and Ashmon Habitats
}

\author{
Hanan, E. Deef ${ }^{1}$, S.A. , Afiah ${ }^{2}$ and Alaa, A. Al-Shahat ${ }^{1}$ \\ ${ }^{I}$ Botany Department, Faculty of Science, Zagazig Univ. and \\ ${ }^{2}$ Plant Genetic Resources Department, Desert Research Center, \\ El-Matareya, Cairo, Egypt.
}

\begin{abstract}
7 HE VARIABILITY of grain storage-proteins of twelve wheat genotypes under stress (Siwa Oasis) and normal (Ashmon) habitats were analyzed using sodium dodecyl sulphate polyacrylamide gel electrophoresis (SDS-PAGE). It was clear that small differences were found in the SDS-PAGE analysis of wheat endosperm proteins among the studied genotypes. The defense isozymes [Peroxidase $(\mathrm{Px})$, Polyphenol oxidase (PPO) and Malate dehydrogenase (Mdh)] were detected and their results concluded a prominent role, either directly or indirectly in stress responses. High polymorphisms were observed in most genotypes for Mdh isozymes at Siwa habitat, meanwhile Px isozymes was decreased. Misr-1 genotype attained higher level of Px isozymes under stress habitat as a trait to tolerance response. The changes of PPO isozymes showed a good correlation with the abiotic stress tolerance of wheat genotypes. Thus, PPO increased in Nesr, S8/17, ACSAD-2, ACSAD-3 and NBL genotypes under stress condition (Siwa habitat).
\end{abstract}

Keywords: Wheat genotypes, Siwa Oasis and Ashmon habitats, Protein profiling, Peroxidase, Polyphenol oxidase and Malate dehydrogenase isozymes.

Wheat (Triticum spp.) is a cereal grain, originally from the Levant region of the Near East but now cultivated worldwide (Belderok et al., 2000). Wheat is considered as one of the most important edible crops in Egypt. It provides approximately one-fifth of the total calorific input of the World's population (FAO, 2010). Currently, about $95 \%$ of the wheat grown worldwide is hexaploid bread wheat, with most of the remaining $5 \%$ being tetraploid durum wheat. In 2010 , world production of wheat was 651 million tons, making it the third mostproduced cereal after maize ( 844 million tons) and rice (672 million tons).

Wheat proteins show high complexity and different interactions with each other, thus making them difficult to be characterized. Usually, they are classified according to their solubility. Following the sequential Osborne extraction procedure, albumins, globulins, gliadins and glutenins are isolated. An alternative classification to that described above has been proposed based on composition and structure rather than solubility (Merlino et al., 2009).

*Corresponding author:hanandeef66@yahoo.com 
Water stress remains one of the most important factors limiting wheat full genetic potential for yield (El-Fadly et al., 2007). Molecular markers developed by analysis of proteins, isozymes and randomly amplified polymorphic DNA (RAPD) have shown excellent potential to assist selection of quantitative traits (Studer, 1992). Altinkut and Gozukirmizi (2003) conducted a study to identify microsatellite markers associated with water-stress tolerance in wheat. They obtained a DNA fragment of $185 \mathrm{bp}$ that was present in the tolerant individuals but not in the sensitive ones. In an attempt to study the relation between stress and storage proteins, Jaradat and Miller (2001) observed that polymorphisms, based on HMW-glutenins, decreased with increasing aridity of the collection site.

Some researchers (Zhang et al., 2000 and Sairam et al., 2001) reported that water stress increased catalase and peroxidase activities in wheat. Polyphenol oxidases (PPO) catalyze the $\mathrm{O}_{2}$-dependent oxidation of mono- and $o$-diphenols to $o$-diquinones, highly reactive intermediates; the secondary reactions that are believed to be responsible for the oxidative browning that occurs as a consequence of plant senescence, wounding and pathogen infection (Campos et al., 2004). Tyagi et al. (2000) showed the roles of PPO in the phenylpropanoid pathway, the Mehler reaction, electron cycling, oxygen regulation, flower petal coloration and plant defense. A defensive role of PPO has frequently been suggested due to the inducibility of PPO in response to various abiotic and biotic injuries or signaling molecules (Maki and Morohashi, 2006). Many of these enzymes have a site for proteolytic processing near the carboxy-terminus (Marusek et al., 2006). The PPO enters into contact with the phenolic compounds in the vacuoles only after the occurrence of some type of damage in the plant (Shimizu et al., 2011).

Malate dehydrogenase (Mdh) functions to maintain malate and pyruvate pools, which are required for operation of the Hatch-Slack cycle and are actively used for neutralization of salt treatment (Eprintsev and Fedorina, 2007). The increase in activity of Mdh was found to be related to salt-induced synthesis of the additional isoforms of Mdh in mesophyll cells (Lea et al., 2007). The accumulating ammonia destroyed the cell membranes, which led to damaging of the plant cells. As established, Malate dehydrogenase glutamate (Mdh-GOT) play key role in catabolism of glutamate (Hong et al., 2004).

Therefore, the objective of this work was to detect biochemical (SDS protein and some isozymes) markers associated with stress tolerance or susceptibility gene (s) in wheat genotypes under Siwa Oasis habitat.

\section{Plant materials}

\section{Material and Methods}

Six genotypes of bread wheat (M1, M2, SH1, L1, L2 and L3), as well as six genotypes of durum wheat (B4, B5, B6, D1, D2 and D3), were used in this study (Table 1). Names, origin, pedigree and/or selection history of the genotypes tested are described by Afiah et al. (2014 and 2015). 
TABLE 1. Names, origin, pedigree and/ or selection history of the twelve wheat genotypes and lines used in the present study of bread (M1, M2, SH1, L1, $\mathrm{L} 2$ and $\mathrm{L3})$ and durum (B4, B5, B6, D1, D2 and D3).

\begin{tabular}{|c|c|c|c|}
\hline Symbol. & Genotype & Origin & Pedigree and/or selection history \\
\hline (M1) & Misr-1 & Egypt & $\begin{array}{l}\text { OASIS/SKAUZ//4*BCN/3/2*PASTOR. } \\
\text { CMSSOOYO } 1881 \mathrm{~T}-050 \mathrm{M}-030 \mathrm{Y}-030 \mathrm{M}-030 \mathrm{WGY}-33 \mathrm{M}- \\
\text { 0Y-0S. }\end{array}$ \\
\hline (M2) & Misr-2 & Egypt & $\begin{array}{l}\text { SKAUZ/BAV } 92 . \\
\text { CMSS96M03611 S-1M-010SY-010M-010SY-8M-0Y-0S. }\end{array}$ \\
\hline (SH1) & Shandaweel-1 & Egypt & $\begin{array}{l}\text { SITE//MO/4/NAC/TH.AC//3*PVN/3/MIRLO/BUC. } \\
\text { CMSS93B00567S-72Y-010M-010Y-010M-0HTY-0SH. }\end{array}$ \\
\hline (L1) & Nesr & $\begin{array}{l}\text { CIMMYT/ } \\
\text { ICARDA\# }\end{array}$ & ICW85-0024-06AP-300AP-300L-1AP-0AP \\
\hline (L2) & $\mathrm{S} 8 / 17 *$ & Egypt & R8 tissue culture regenerated double haploid plant \\
\hline (L3) & Line $-606^{*}$ & Egypt & $\begin{array}{l}\text { Atlas 66/Nap Hall//(NE 70117) SkoresPelka 35/2*RCB - } 61 \\
\mathrm{Su} 606-13 \mathrm{Su}-2 \mathrm{Su}-5 \mathrm{Su}-0 \mathrm{Su}\end{array}$ \\
\hline (B4) & Baniseuf-4 & Egypt & $\begin{array}{l}\text { AUSL/5/CANDO/4/BY*2/TACE//II } \\
\text { 27655/3/TME//ZB/W*2. } \\
\text { ICD88-1120-ABL-0TR-1BR-0TR-6AP-0AP-0SD. }\end{array}$ \\
\hline (B5) & Baniseuf-5 & Egypt & $\begin{array}{l}\text { DIPPERZ/BUSHEN3. } \\
\text { CDSS 92B128-1M-0Y-0M-0Y-3B-0Y-0SD. }\end{array}$ \\
\hline (B6) & Baniseuf-6 & Egypt & $\begin{array}{l}\text { BOOMER-21/BUSCA-3. } \\
\text { CDSS 95Y001185-8Y-0M-0Y-0B-1Y-0B0SD. }\end{array}$ \\
\hline (D1) & ACSAD-2 & ACSAD & Gediz"S"- Bar," S"/ Ege // Ruf,"'S" - FG”S". \\
\hline (D2) & ACSAD-3 & ACSAD & $\begin{array}{l}\text { MZA" S" × 21563- AA"S"/ PG"S"- FG"S"×GTA"S" } \\
\times 21563-\text { AA"S"/ } 2\end{array}$ \\
\hline (D3) & $\mathrm{NBL}^{* *}$ & Egypt & $\begin{array}{l}\text { (Mexi 'S'/ Mgha/ 51792// D. } 6 \text { - CD 9799) /(ICD 85- } \\
\text { 1328- ABL) } \\
\text { 9Hekma-8Mat -11Mar-6Mar-3Mar- OMar }\end{array}$ \\
\hline$I M M Y T$ & entro Interna & onal de Mej & $\begin{array}{l}\text { ramiento de Maize Y Trigo (Mexico) } \\
\text { ement center. } \\
\text { icultural Research in the Dry Areas. }\end{array}$ \\
\hline
\end{tabular}

Methods

Grains were sown under Siwa Oasis and Ashmon conditions on Nov., 2012. Grains were sown in three replications at an adjusted rate 300 viable grain $/ \mathrm{m}^{2}$. Normal agronomic practices were performed; more details of soil and irrigation water chemical analysis are mentioned by Afiah et al. (2014). Metrological parameters were obtained from the observatory at each research station and daily minimum and maximum temperature and rainfall were recorded (Afiah et al., 2014). The molecular and biochemical studies were conducted at Botany Dept., Faculty of Science, Zagazig Univ and Microbial Genetics Lab., Genetics Dept., Fac. of Agriculture, Kafr El-Sheikh. 
Protein analysis

Total proteins were extracted from all genotype leaves under stress (Siwa habitat) and normal (Ashmon habitat) conditions as in El-Fadly et al. (2007). The extracted proteins were electrophoresed using SDS-PAGE and stained according to Laemmli (1970). The banding patterns and the molecular weight were determined against standard M.Wt. markers [Pharmacia Biotech Cat. No.17$0446(10-225 \mathrm{kDa})]$.

\section{Isozymes Electrophoresis}

Native-polyacrylamide gel electrophoresis (Native-PAGE) was conducted to identify isozyme variations among the studied genotypes using three isozyme systems according to Stagemann et al. (1985). Fresh and young leave samples for each genotype and location were used separately for isozymes extraction. The studied isozymes are those of peroxidase (Px), polyphenol oxidase (PPO) and malate dehydrogenase (Mdh). Separation of isoenzymes of Px, PPO and Mdh were performed by Native PAGE (30\% polyacrylamide) by loading $50 \mu \mathrm{g}$ of protein. The gels were run in an electrode buffer composed of $0.025 \mathrm{M}$ Tris and glycine $0.192 \mathrm{M}(\mathrm{pH} 8.8)$ for $3 \mathrm{~h}$ at $40^{\circ} \mathrm{C}$ at a constant current of $30 \mathrm{~mA}$.

Isozyms staining and detection (Scialabba et al., 2002)

After electrophoresis, the gels were stained according to their enzyme systems with the appropriate substrate and chemical solutions then incubated at room temperature in dark for complete staining. In most cases, incubation for about 1 to $2 \mathrm{hr}$ was enough.

Peroxidase (Px)

Benzidine di $\mathrm{HCl}(0.125 \mathrm{~g})$, glacial acetic acid $(2 \mathrm{ml})$ and D.W (up to $50 \mathrm{ml})$. Gel was placed into this solution and 5 drops of hydrogen peroxide were added. The gel was incubated at room temperature until bands appearance (Brown, 1978).

Polyphenol Oxidase (PPO)

After electrophoresis, the gel was soaked in $0.1 \mathrm{M}$ sodium mono di Phosphate buffer (pH 6.8) solved in $100 \mathrm{mg}$ sulfanilic acid, and then mixed with $30 \mathrm{mg}$ athecol solved in $1 \mathrm{ml}$ acetone. The gel was incubated at $37^{\circ} \mathrm{C}$ until bands appeared (Gauillard et al., 1993).

Malate dehydrogenase (Mdh)

$0.1 \mathrm{M}$ Tris-pH (7.5), $100 \mathrm{ml}$ NAD (30 mg), MTT (20 mg), PMS (5 mg) and maleic acid $(1.2 \mathrm{~g})$ were mixed. The gel was placed into this solution and incubated at $30^{\circ} \mathrm{C}$ for $30 \mathrm{~min}$ until bands appeared (Tesfaye et al., 2001).

\section{Results and Discussion}

\section{A. SDS-PAGE analysis of protein}

Figure 1.a \& b. shows the electrophoretic banding pattern of proteins in the tested wheat genotypes under stress (Siwa habitat) as well as under normal habitat (Ashmon habitat). A total of 10 bands with different molecular weights were scored. These bands were not necessarily appearing in all genotypes. All genotypes

Egypt. J. Bot., 56, No. 1 (2016) 
under the two conditions exhibited 5 common bands i.e. No. 1, 2, 4, 5 and 6 with molecular weight $10,25,50,75$ and $100 \mathrm{kDa}$, respectively. These bands may be considered as biochemical marker for wheat genotypes under normal and stress conditions. SDS-PAGE shows no new proteins synthesized under Siwa stress condition, moreover protein of $35 \mathrm{kDa}$ disappeared in the genotypes of Siwa habitat. The reduction in protein content due to salinity or water stress might be due to increase of proteolysis or inhibition of protein synthesis (Dey and Kar, 1995). Wyedert and Cullen (2010) revealed that protein synthesis was reduced by stress, but a greater effect of stress was shown as protein degradation. Therefore, protein profiles (SDS-PAGE) could be useful markers in genotypes adaptation, on improving the efficiency of wheat breeding programs. Nemati et al. (2012) concluded that protein profiles could be useful markers for cultivar identification, registration of new varieties, pedigree analysis and studies of genetic diversity and classification of adapted cultivars. The variation found in protein profiles within the present study might be a response to the extreme conditions of Siwa habitat. This conclusion agrees with that of Marcos-Filho (2005).

$\mathbf{a}$

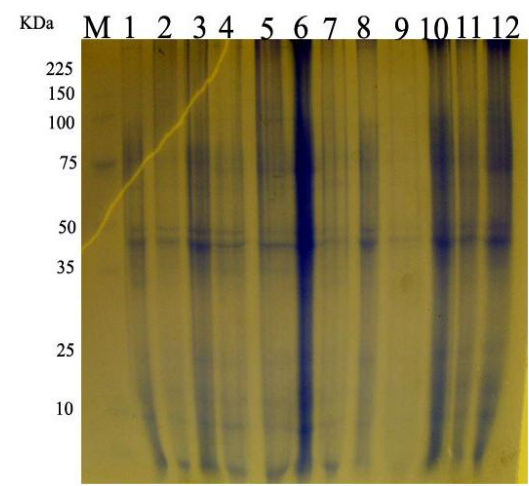

SDS-PAGE b

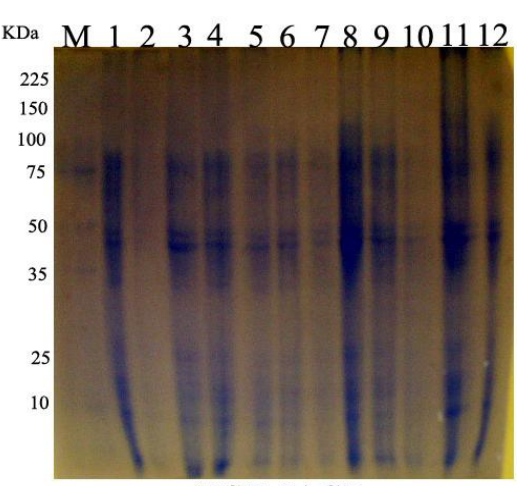

DSD-PAGE

Fig. 1. Protein profile of bread (M1, M2, SH1, L1, L2 and L3) and durum

(B4, B5, B6, D1, D2 and D3) wheat genotypes.

$\begin{array}{ll}\text { a. under stress (Siwa habitat) } & \text { b. under normal condition (Ashmon }\end{array}$ habitat).

\section{B. Isozyme electrophoresis}

B.1. Polymorphisms of peroxidase isozymes:

Figure 2:a,b and Table 2:a,b show the peroxidase banding patterns of the different wheat genotypes under study exhibited from four to three bands at normal and stress conditions, respectively. The first three bands of peroxidase isozymes were detected for all genotypes under stress (Siwa habitat) and normal 
(Ashmon habitat) conditions. Three bands with high density were found in genotype M1 at Siwa habitat, whereas at Ashmon habitat, M2 had three and B5 had four high density bands. The first band $(\mathrm{Px} 1, \mathrm{RF}=0.1)$ was decreased in genotypes at Ashmon habitat, compared to genotypes at Siwa habitat. The fourth band $(\mathrm{Px} 4, \mathrm{RF}=0.5)$ disappeared completely from genotypes at Siwa habitat and some genotypes at Ashmon habitat. Dasgupta et al. (2010) reported that four peroxidase isoforms were observed under control and salinity treatment in some mangrove species. Deef et al. (2014) showed that M1 and M2 are tolerant genotypes of bread wheat's and may be recommended to be cultivate under Siwa Oasis habitat. Meanwhile, the reverse was true at durum genotypes i.e. most yield and tolerant genotypes D3 and D1 (under Siwa Oasis habitat) showed least peroxidase intensity bands. Cluster and principal component analysis, based on eleven of stress tolerance indices, revealed that D3 and D1 were the most stress tolerant genotypes of durum wheat (under Siwa Oasis habitat) (Afiah et al., 2015).

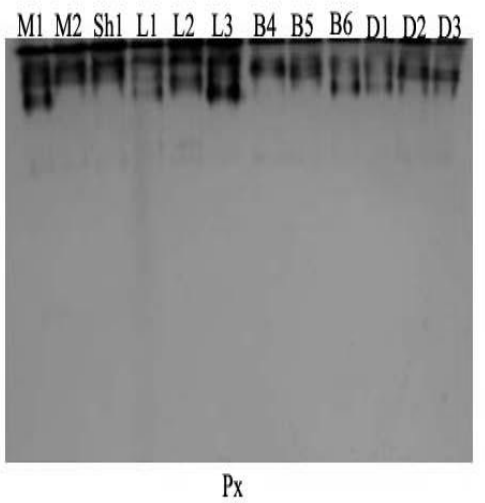

Px

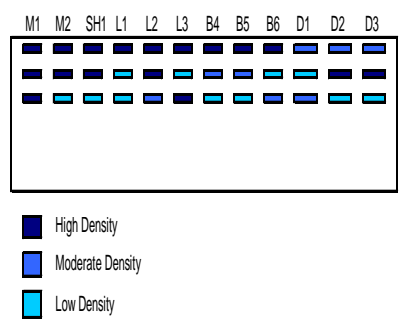

b
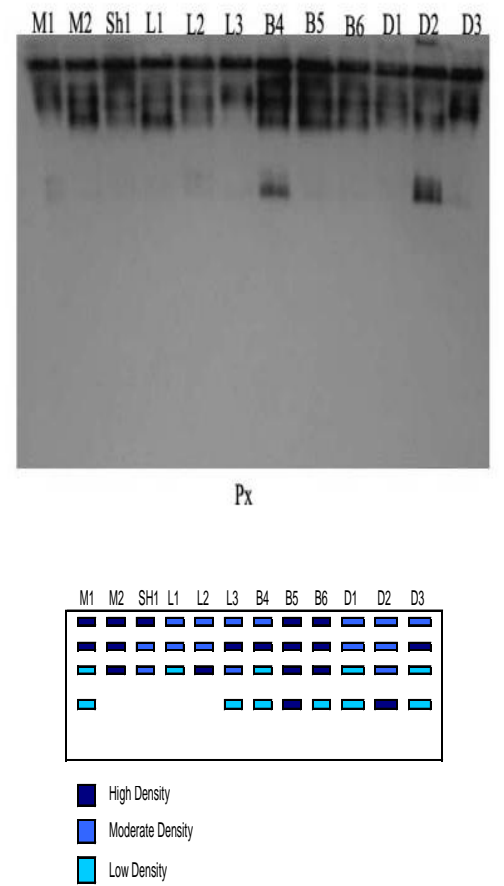

Fig. 2. Photograph of electrophoretic peroxidase isozyme patterns of bread (M1, M2, SH1, L1, L2 and L3) and durum (B4, B5, B6, D1, D2 and D3) wheat genotypes.

a. under stress (Siwa habitat) b. under normal condition (Ashmon habitat). 
TABLE 2. Peroxidase isozymes intensity of bread (M1, M2, SH1, L1, L2 and L3) and durum (B4, B5, B6, D1, D2 and D3) wheat genotypes.

a. under stress (Siwa habitat) b. under normal condition (Ashmon habitat).

habitat).
\begin{tabular}{|l|l|c|c|c|c|c|c|c|c|c|c|c|c|}
\hline $\begin{array}{l}\text { Peroxidase } \\
\text { isozymes }\end{array}$ & RF & & \multicolumn{10}{|c|}{ bread } \\
\cline { 3 - 13 } & & M1 & M2 & SH1 & L1 & L2 & L3 & B4 & B5 & B6 & D1 & D2 & D3 \\
\hline Px1 & 0.1 & $1^{++}$ & $1^{++}$ & $1^{++}$ & $1^{++}$ & $1^{++}$ & $1^{++}$ & $1^{++}$ & $1^{++}$ & $1^{++}$ & $1^{+}$ & $1^{+}$ & $1^{+}$ \\
\hline Px2 & 0.2 & $1^{++}$ & $1^{++}$ & $1^{++}$ & $1^{-}$ & $1^{++}$ & $1^{-}$ & $1^{+}$ & $1^{+}$ & $1^{-}$ & $1^{-}$ & $1^{++}$ & $1^{++}$ \\
\hline Px3 & 0.3 & $1^{++}$ & $1^{-}$ & $1^{-}$ & $1^{-}$ & $1^{+}$ & $1^{++}$ & $1^{-}$ & $1^{-}$ & $1^{+}$ & $1^{+}$ & $1^{-}$ & $1^{-}$ \\
\hline
\end{tabular}

b

\begin{tabular}{|c|c|c|c|c|c|c|c|c|c|c|c|c|c|}
\hline \multirow{2}{*}{$\begin{array}{c}\text { Peroxidase } \\
\text { isozymes }\end{array}$} & \multirow{2}{*}{ RF } & \multicolumn{6}{|c|}{ bread } & \multicolumn{6}{|c|}{ durum } \\
\hline & & M1 & M2 & SH1 & L1 & L2 & L3 & B4 & B5 & B6 & D1 & D2 & D3 \\
\hline Px1 & 0.1 & $1^{++}$ & $1^{++}$ & $1^{++}$ & $1^{+}$ & $1^{+}$ & $1^{+}$ & $1^{+}$ & $1^{++}$ & $1^{++}$ & $1^{+}$ & $1^{+}$ & $1^{+}$ \\
\hline Px2 & 0.2 & $1^{++}$ & $1^{++}$ & $1^{+}$ & $1^{+}$ & $1^{+}$ & $1^{++}$ & $1^{++}$ & $1^{++}$ & $1^{++}$ & $1^{+}$ & $1^{+}$ & $1^{++}$ \\
\hline Px3 & 0.3 & $1^{-}$ & $1^{++}$ & $1^{+}$ & $1^{-}$ & $1^{++}$ & $1^{+}$ & $1^{-}$ & $1^{++}$ & $1^{++}$ & $1^{-}$ & $1^{+}$ & $1^{-}$ \\
\hline $\mathrm{Px} 4$ & 0.5 & $1^{-}$ & 0 & 0 & 0 & 0 & $1^{-}$ & $1^{-}$ & $1^{++}$ & $1^{-}$ & $1^{-}$ & $1^{++}$ & $1^{-}$ \\
\hline
\end{tabular}

$1^{++}=$High Density, $1^{+}=$Moderate Density, $1^{-}=$Low Density, $0=$ Absent

\section{B. 2. Polymorphisms of polyphenol oxidase isozymes}

The obtained results in Fig. 3: a,b and Table 3:a,b showed that two polyphenol oxidase(PPO) isozymes were detected in the wheat genotypes under the two conditions under study. Generally, stress (Siwa habitat) showed higher density isozyme polymorphisms of polyphenol oxidase in most genotypes. It is clearly noticeable that no clear relationship is evident between polyphenol oxidase isozymes and stress tolerance or susceptibility in wheat with exception of few bands. PPO are synthesized in the cytoplasm in the form of preproteins (60$70 \mathrm{kDa}$ ) and have a signal peptide in the amino terminus, which internalizes them in the chloroplast, where they are processed by stromal peptidases into functional proteins (54-62 kDa) and then imported into the thylakoid lumen (Marusek et al., 2006).

PPO in the mesophyll chloroplast has been proposed to have a role in the Mehler reaction, photo reduction of molecular oxygen by PSI, and regulation of plastidic oxygen levels (Trebst and Depka, 1995, Badger et al., 2000). The Mehler reaction is a potentially important nondestructive sink for excess photosynthetic electrons under conditions of water stress (Siwa habitat) compared with normal condition (Ashmon) may help prevent over-reduction of components of linear electron transport, in agreement with Haupt-Herting and Fock (2002). When excess excitation energy is not dissipated by protective mechanisms, it is used to form cytotoxic ROS (Maki and Morohashi, 2006). Photoinhibition and ultimately photooxidative damage will occur if the combined capacity of ROS scavenging systems is exceeded. D2 and D3 genotypes of elevated PPO are expected to have improved stress tolerance due to contribute to the Mehler reaction. 
Our results evaluated the response of tolerant wheat genotypes to stress (Siwa habitat) condition with increased PPO activity. It an adaptive strategy under water stress since it could reduce further water loss and allow limited nutrients to be partitioned to younger tissues (Thipyapong, et al., 2004). Induction of PPO activities under water stress has been previously demonstrated in tomatoes (English-Loeb et al., 1997) and in coconut (Shivishankar, 1988). However, further investigation is needed to well-defined responsiveness of PPO to various abiotic and biotic stresses, depending on plant genotype and environmental as well as ecological context, may be an adaptive strategy of plants to cope with a multitude of stresses that often occur simultaneously (Krishnamoorthy et al., 2004 \& Raj et al., 2006).

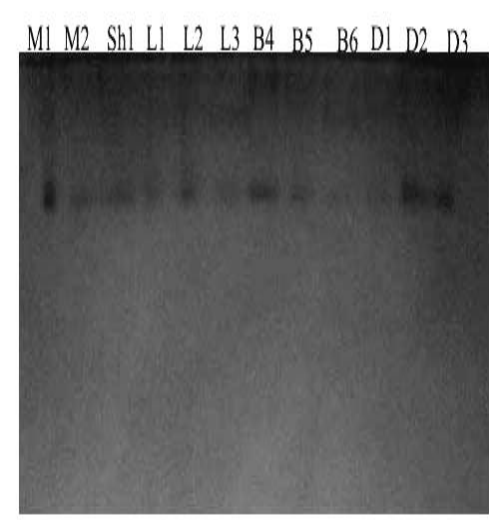

PP0

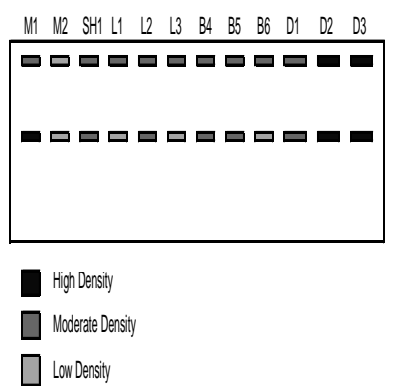

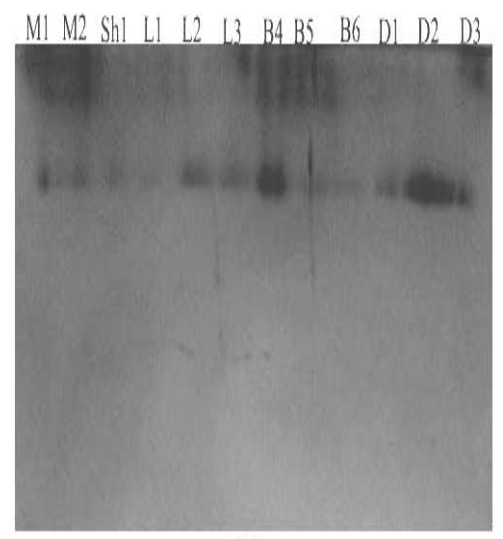

$\mathrm{PP} 0$

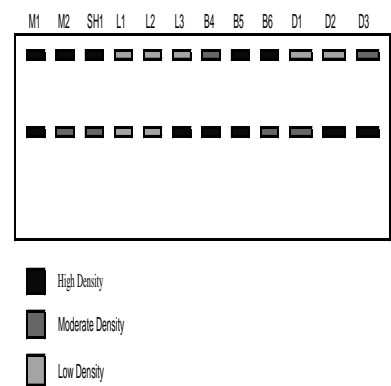

Fig. 3. Photograph of electrophoretic polyphenol oxidase isozyme patterns of bread (M1, M2, SH1, L1, L2 and L3) and durum (B4, B5, B6, D1, D2 and D3) wheat genotypes.

a. under stress (Siwa habitat) b. under normal condition (Ashmon habitat). 
TABLE 3. Polyphenol oxidase isozyme intensity of bread (M1, M2, SH1, L1, L2 and L3) and durum (B4, B5, B6, D1, D2 and D3) wheat genotypes. a a. under stress (Siwa habitat) b. under normal condition (Ashmon habitat).

\begin{tabular}{|c|c|c|c|c|c|c|c|c|c|c|c|c|c|}
\hline $\begin{array}{c}\text { Polyphenol } \\
\text { oxidase } \\
\text { isozymes }\end{array}$ & RF & M1 & M2 & SH1 & L1 & L2 & L3 & B4 & B5 & B6 & D1 & D2 & D3 \\
\hline PPO1 & 0.1 & $1^{+}$ & $1^{-}$ & $1^{+}$ & $1^{+}$ & $1^{+}$ & $1^{+}$ & $1^{+}$ & $1^{+}$ & $1^{+}$ & $1^{+}$ & $1^{++}$ & $1^{++}$ \\
\hline PPO2 & 0.4 & $1^{++}$ & $1^{-}$ & $1^{+}$ & $1^{-}$ & $1^{+}$ & $1^{-}$ & $1^{+}$ & $1^{+}$ & $1^{-}$ & $1^{+}$ & $1^{++}$ & $1^{++}$ \\
\hline
\end{tabular}

b

\begin{tabular}{|c|c|c|c|c|c|c|c|c|c|c|c|c|c|}
\hline \multirow{2}{*}{$\begin{array}{l}\text { Polyphenol } \\
\text { oxidase } \\
\text { isozymes }\end{array}$} & \multirow{2}{*}{ RF } & \multicolumn{6}{|c|}{ bread } & \multicolumn{6}{|c|}{ durum } \\
\hline & & M1 & M2 & SH1 & L1 & L2 & L3 & B4 & B5 & B6 & D1 & D2 & D3 \\
\hline PPO1 & 0.1 & $1^{++}$ & $1^{++}$ & $1^{++}$ & $1^{-}$ & $1^{-}$ & $1^{-}$ & $1^{+}$ & $1^{++}$ & $1^{++}$ & $1^{-}$ & $1^{-}$ & $1^{+}$ \\
\hline PPO2 & 0.4 & $1^{++}$ & $1^{+}$ & $1^{+}$ & $1^{-}$ & $1^{-}$ & $1^{++}$ & $1^{++}$ & $1^{++}$ & $1^{+}$ & $1^{+}$ & $1^{++}$ & $1^{++}$ \\
\hline
\end{tabular}

$1^{++}=$High Density, $1^{+}=$Moderate Density, $1^{-}=$Low Density, $0=$ Absent

\section{B.3. Polymorphisms of malate dehydrogenase isozymes}

The results of polyacrylamide gel electrophoresis on malate dehydrogenase (Mdh) isozymes of wheat genotypes under normal (Ashmon habitat) and stress (Siwa habitat) conditions are shown in Fig. 4:a,b and Table 4:a,b. The isozyme profiles showed four bands for malate dehydrogenase. These bands occurred in all genotypes under the two studied conditions. Genotypes cultivated at Siwa (stress) had higher activities of Mdh in all genotypes. The fourth band (Mdh4, $\mathrm{RF}=0.9$ ) was detected with high density for all genotypes under stress (Siwa habitat) and normal (Ashmon habitat) conditions. Similar results were previously obtained by Sairam et al. (2001) and Zhang et al. (2000), who observed that water stress, increased some isozyme polymorphisms. Thus, the activity of Mdh is serving as objective enzyme test for determining cereal genotypes with high tolerance to salt stress.

\section{Conclusion}

Protein profiles (SDS-PAGE) could be useful markers for genotypes adaptation, by improving the efficiency of wheat breeding programs. The most stress tolerant genotypes D3 and D1 (under Siwa Oasis habitat) showed least peroxidase intensity bands. PPO isozyme intensity was increased in response to stress with highest magnitude of induction in older leaves and corresponding abscission zones. It might facilitate cell death preferentially in these tissues, as an adaptive strategy under stress, since it could reduce further water loss and allow limited nutrients to be partitioned to younger tissues. Wheat genotypes with high Mdh activity should have greater tolerance to stress, whereas low Mdh activity would indicate less tolerance. 


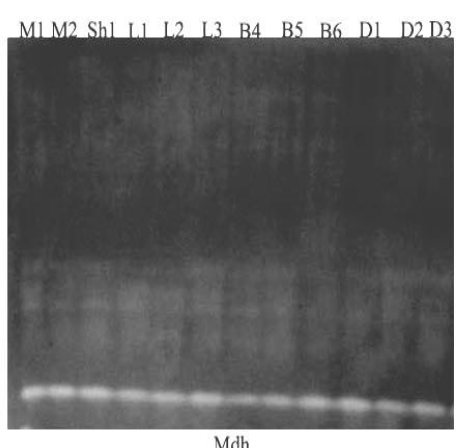

Mdh

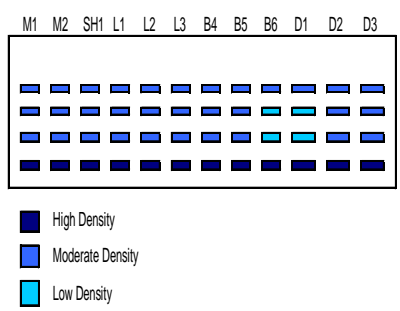

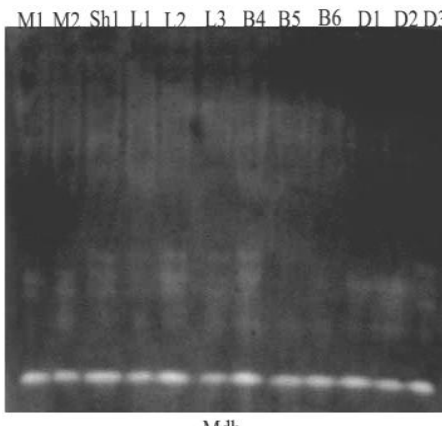

Mdh

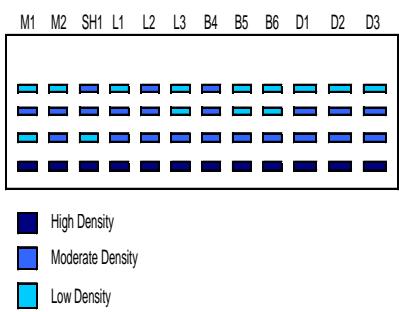

Fig. 4. Photograph of electrophoretic malate dehydrogenase isozyme patterns of bread (M1, M2, SH1, L1, L2 and L3) and durum (B4, B5, B6, D1, D2 and D3) wheat genotypes.

a. under stress (Siwa habitat) b. under normal condition (Ashmon habitat).

TABLE 4. Malate dehydrogenase isozyme intensity of bread (M1, M2, SH1, L1, L2 and L3) and durum (B4, B5, B6, D1, D2 and D3) wheat genotypes.

\begin{tabular}{|c|c|c|c|c|c|c|c|c|c|c|c|c|c|}
\hline \multirow{2}{*}{$\begin{array}{l}\text { Malate } \\
\text { Dehydrog } \\
\text { enase } \\
\text { isozymes }\end{array}$} & \multirow[b]{2}{*}{ RF } & \multicolumn{6}{|c|}{ bread } & \multicolumn{6}{|c|}{ durum } \\
\hline & & M1 & M2 & SH1 & L1 & L2 & L? & B & $\mathbf{B}$ & B6 & D1 & D2 & D3 \\
\hline Mdh1 & 0.5 & $1^{+}$ & $1^{+}$ & $1^{+}$ & $1^{+}$ & $1^{+}$ & $1^{+}$ & 1 & 1 & $1^{+}$ & $1^{+}$ & $1^{+}$ & $1^{+}$ \\
\hline $\operatorname{Mdh} 2$ & 0.6 & $1^{+}$ & $1^{+}$ & $1^{+}$ & $1^{+}$ & $1^{+}$ & $1^{t}$ & 1 & 1 & $1^{-}$ & $1^{-}$ & $1^{+}$ & $1^{+}$ \\
\hline Mdh3 & 0.7 & $1^{+}$ & $1^{+}$ & $1^{+}$ & $1^{+}$ & $1^{+}$ & $1^{+}$ & 1 & 1 & $1^{-}$ & $1^{-}$ & $1^{+}$ & $1^{+}$ \\
\hline Mdh4 & 0.9 & $1^{++}$ & $1^{++}$ & $1^{++}$ & $1^{++}$ & $1^{+}$ & $1^{+}$ & $1^{+}$ & 1 & $1^{++}$ & $1^{++}$ & $1^{++}$ & $1^{++}$ \\
\hline
\end{tabular}

b

\begin{tabular}{|l|c|c|c|c|c|c|c|c|c|c|c|c|c|}
\hline $\begin{array}{l}\text { Malate } \\
\text { Dehydroge } \\
\text { nase }\end{array}$ & \multirow{2}{*}{$\begin{array}{l}\text { RF } \\
\text { isozymes }\end{array}$} & M1 & M2 & SH1 & L1 & L2 & L3 & B4 & B5 & B6 & D1 & D2 & D3 \\
\hline Mdh1 & 0.5 & $1^{-}$ & $1^{-}$ & $1^{+}$ & $1^{-}$ & $1^{+}$ & $1^{-}$ & $1^{+}$ & $1^{-}$ & $1^{-}$ & $1^{-}$ & $1^{-}$ & $1^{-}$ \\
\hline Mdh2 & 0.6 & $1^{+}$ & $1^{+}$ & $1^{+}$ & $1^{+}$ & $1^{+}$ & $1^{-}$ & $1^{+}$ & $1^{-}$ & $1^{-}$ & $1^{+}$ & $1^{+}$ & $1^{+}$ \\
\hline Mdh3 & 0.7 & $1^{-}$ & $1^{+}$ & $1^{-}$ & $1^{+}$ & $1^{+}$ & $1^{+}$ & $1^{+}$ & $1^{+}$ & $1^{+}$ & $1^{+}$ & $1^{+}$ & $1^{+}$ \\
\hline Mdh4 & 0.9 & $1^{++}$ & $1^{++}$ & $1^{++}$ & $1^{++}$ & $1^{++}$ & $1^{++}$ & $1^{++}$ & $1^{++}$ & $1^{++}$ & $1^{++}$ & $1^{++}$ & $1^{++}$ \\
\hline
\end{tabular}

$1^{++}=$High Density, $1^{+}=$Moderate Density, $1^{-}=$Low Density, $0=$ Absent.

Egypt. J. Bot., 56, No. 1 (2016) 


\section{References}

Afiah, S.A., Deef, H. E. and Al-Shahat, A. A. (2014) Inter simple sequence repeats and salt tolerance indices for assessing some bread wheat genotypes under two diverse environments. Annuals of Agric. Sci., Spissue, 59(2): 349-366.

Afiah, S.A., Deef, H. E. and Al-Shahat, A.A. (2015) Identifying susceptible and tolerant durum wheat genotypes to Siwa Oasis habitat compared to that of Ashmon habitat. $J$. Biol. Chem. Environ. Sci., in press.

Altinkut, A. and Gozukirmizi, N. (2003) Search for microsatellite associated with water stress tolerance in wheat through bulked segregant analysis. Molecular Biotech., 23: 67-106.

Badger, M. R., von Caemmerer, S., Ruuska, S. and Nakano, H. (2000) Electron flow to oxygen in higher plants and algae: rates and control of direct photoreduction (Mehler Reaction) and rubisco oxygenase. Phil. Trans. R. Soc. Lond. B., 355: 14331446 .

Belderok, R.B., Mesdag, H. and Dingena, A. (2000) "Bread-Making Quality of Wheat", Springer, p. 3.

Brown, A.H.D. (1978) Isozymes, plant population genetic structure and genetic conservation. Theoretical and Applied Genetics, 52(4):145-157.

Campos, A. D. Ferreira, A. G., Vozarí Hampe, M. M., Antunes, I. F., Brancão, N., da Silveira, E. P., Osório, V. A. and Augustin, E. (2004) Peroxidase and polyphenol oxidase activity in bean anthracnose Resistance. Pesq. Agropec. Bras. Brasilia., 39: 637-643.

Dasgupta, N., Nandy Datta, P., Tiwari, C. and Das, S. (2010) Salinity-imposed changes of some isozymes and total leaf protein expression in five mangroves from two different habitats. J. Plant Interactions, 5(3): 211-221.

Deef, H.E., Afiah, S. A. and Al-Shahat, A.A. (2014) Physiological studies and tolerance indices of six bread wheat genotypes under Siwa Oasis and Ashmon habitats. Egypt. J. Bot., in press.

Dey, S. K. and Kar, M. (1995) Antioxidant efficiency during callus initiation from mature rice embryo. Plant Cell Physiol., 36: 543-549.

El-Fadly, G. A. B., Menshawy, A. M. and Farhat, W. Z. E. (2007) Molecular and biochemical studies on some bread wheat genotypes in relation to water stress tolerance. African Crop Science Conference Proc., Printed in El-Minia, Egypt, 8: 605612.

English-Loeb, G., Stout, M. J. and Duffey, S. S. (1997) Drought stress in tomatoes: changes in plant chemistry and potential nonlinear consequences for insect herbivores, OIKOS, 79: 456- 468.

Eprintsev, A. and Fedorina, O. (2007) Functioning of malate dehydrogenase system in mesophyll and bundle sheath cells of maize leaves under salt stress conditions. Russian J. Plant Physiol., 54 (6): 728. 
FAO (Food and Agriculture Organization) (2010) FAOSTAT database. [Accessed on 10 December 2010]. Available online: http://www.faostat.fao.org/.

Gauillard, F., Richard-Forget, F. and Nicholas, J. (1993) New Spectrophotometric assay for polyphenol oxidase activity, Ibid., 215:59-65.

Haupt-Herting, S. and Fock, H. P. (2002) Oxygen exchange in relation to carbon assimilation in water-stressed leaves during photosynthesis. Annals Bot., 89: 851-859.

Hong, H. T. K., Nose, A. and Agarie, S. (2004) Oxidation of substrate in Percoll-purified mitochondria isolated from Kalanchoe" daigremontiana. Bulletin of the Faculty of Agriculture, Saga University, 89:121-129.

Jaradat, A. A. and Miller, J. (2001) Spatial and temporal genetic structure of wild emmer wheat in Jordan. II. High-molecular-weight glutenins and allozymes. Israel $J$. Plant Sci., 49: 65-76.

Krishnamoorthy, V., Kumar, N., Angappan, K. and Soorianathasundaram, K. (2004) Evaluation of new banana hybrids against black leaf streak disease. Infomusa., 13: 2527.

Laemmli, U.K. (1970) Cleavage of structural proteins during the assembly of head of bacteriophage T4. Nature, 227: 680-685.

Lea, P. J., Sodek, L., Parry, M. A. J., Shewry, P. R. and Halford, N. G. (2007) Asparagine in plants. Ann Appl Biol., 150: pp.1-26.

Maki, H. and Morohashi, Y. (2006) Development of polyphenol oxidase activity in the micropylar endosperm of tomato seeds. J. Plant Physiol., 163: 1-10.

Marcos-Filho, J. (2005) Fisiologia de sementes de plantas cultivadas. Piracicaba: FEALQ, 495.

Marusek, C. M., Trobaugh, N. M., Flurkey, W. H. and Inlow, J. K. (2006) Comparative analysis of polyphenol oxidase from plant and fungal species. J. Inorg. Biochem., 100:108-123.

Merlino, M., Leroy, P., Chambon, C. and Branlard, G. (2009) Mapping and proteomic analysis of albumin and globulin proteins in hexaploid wheat kernels (Triticum aestivum L.) Theor. Appl. Genet., 18:1321-1337.

Nemati, M., Bazdar, J. and Hokmalipour, S. (2012) Study of total seed storage protein in wheat varieties based on sodium dodecyl sulfate polyacrylamide gel electrophoresis (SDS-PAGE). Tech. J. Engin. App. Sci., 2 (2): 39-43.

Raj, S. N., Sarosh, B. R. and Shetty, H. S. (2006) Induction and accumulation of polyphenol oxidase activities as implicated in development of resistance against pearl millet downy mildew disease. Funct. Plant Biol., 33: 563-571. 
Sairam, R.K., Chandrasekar, V. and Srivastava, G.C. (2001) Comparison of hexaploid and tetraploid wheat cultivars in their responses to water stress. Biol. Plant., 44(1): 8994.

Scialabba, A., Bellani, L. M. and Dell Aquila, A. (2002) Effects of ageing on peroxidase activity and localization in radish (Raphanus sativus L.) seeds. Eur. J. Histochem., 46: 351-358.

Shimizu, M. M., Melo, G. A., Brombini dos Santos, A., Bottcher, A., Cesarino, I., Araújo, P.;Magalhães, J. C. and Mazzafera, P. (2011) Enzyme characterization, isolation and cDNA cloning of polyphenol oxidases in the hearts of palm of three commercially important species. Plant Physiol. Biochem., 49: 970-977.

Shivishankar, S. (1988) Polyphenol oxidase isozymes in coconut genotypes under water stress. Plant Physiol. Biochem., 15: 87-91.

Stagemann, H., Burgermeister, W., Frankcksen, H. and Krogerreckenfort, E. (1985) Manual of gel electrophoresis and isoelectric focusing with the apparatus PANTA- PHOR. Inst. Biochem. Messeweg 11, D- 3300. Braunschweig, West Germany.

Studer, C. W. (1992) Biochemical and molecular markers in plant breeding. Plant Breed. Rev., 9: 37-61.

Tesfaye, M., Temple, S.J., Allan, D.L., Vance, C.P. and Samac, D.A. (2001) Overexpression of malate dehydrogenase in transgenic alfalfa enhances organic acid synthesis and confers tolerance to aluminum. Plant Physiol., 127: 1836-1844.

Thipyapong, P., Melkonian, J., Wolfe, D. W. and Steffens, J. C. (2004) Suppression of polyphenol oxidases increases stress tolerance in tomato. Plant Sci., 167: 693-703.

Trebst, A. and Depka, B. (1995) Polyphenol oxidase and photosynthesis research. Photosynth. Res., 46: 41-44.

Tyagi, M., Kayastha, A. M. and Sinha, B. (2000) The role of peroxidase and polyphenol oxidase isozymes in wheat resistance to Alternaria triticina. Biol. Plant, 43: 559-562.

Wyedert, C. J. and Cullen, J. J. (2010) Measurement of superoxide dismutase, catalase, and glutathione peroxidase in cultured cells and tissue. Nat. Protoc., 5(1): 51-66.

Zhang, Q. H., Liu, H. S., Meng, F. T., Zhang, S.T., Zhang, Z. H. and Kang, G. Z. (2000) The effect of drought stress on physiological characters of leaves and seedfilling characteristics of the new wheat cultivar Yamai 36 during the late developmental stage. Scientia. Agricultura. Sinica., 33(4): 94-96.

(Received 17/11/2014 accepted 8/7/2015) 


\section{تباين نظائر الانزيمات لبعض التراكيب الوراثية للقمح تحت ظروف بيئتي واحة سيوة و أشمون}

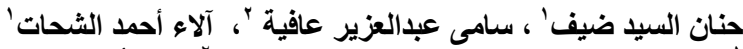

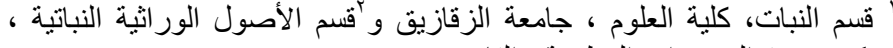

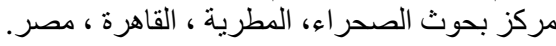

تم تحليل البروتينات لاثنتى عشرة سلالة ور اثية لنبات القمح باستخدام

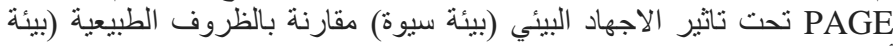
أشمون). واظهرت النتائج تباينا كميا وكيفيا محدودا بين النينة السلالات النيات النامية في بيئة

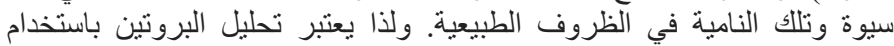

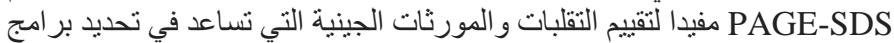

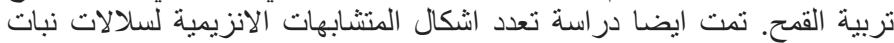

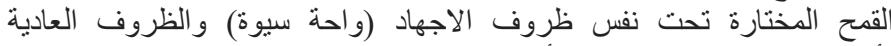

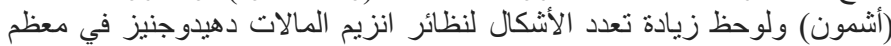

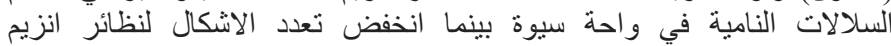

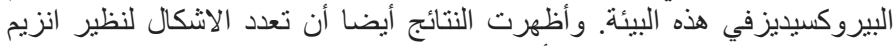

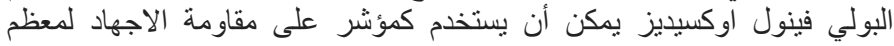

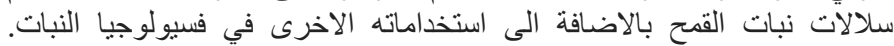

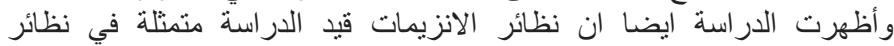

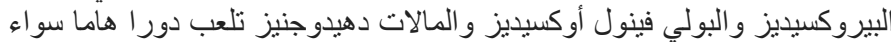
بشكل مباشر أو غير مباشر في مقاومة الاجهاد البيئي. 